\title{
SECTION 734 OF THE INTERNAL REVENUE CODE
}

\author{
BY HARRY J. RUDICK $†$
}

To profit from one's own mistakes has traditionally been considered the hallmark of a wise man. The taxpayer who attempts to pursue this ancient path to wisdom, however, will find the road strewn with Congressionally created obstacles, such as section $734^{1}$ of the Internal Revenue Code. The kind of profitable error which section 734 is designed to prevent can be shown by a relatively simple illustration. Corporation $A$ in 1938 sold some property at a profit of $\$ 100,000$ and reported this profit as a capital gain. It offset this gain by capital losses of an equal amount and hence paid no tax on the $\$ 100,000$. If the gain had been considered ordinary income rather than capital gain, the capital losses could not have been availed of and the $\$ 100,000$ would have been taxable. In 1942 Corporation $A$, which computes its excess profits credit under the income method, ${ }^{2}$ discovers that the 1938 profit was $n 0$ l a capital gain, that it was ordinary income, and that its excess profits credit should be increased by $\$ 25,000$, resulting in a 1942 tax saving of approximately $\$ 10,000$. Accordingly, it claims in its 1942 excess profits tax return a credit based on the inclusion in base period income of the $\$ 100,000$. The Commissioner of Internal Revenue challenges the company's position, but the company successfully litigates the issue. ${ }^{3}$ At this point section 734 enters the picture and adds to the 1942 excess profits tax liability of Corporation $A$ the saving in income tax (plus interest thereon) which resulted from the erroneous and inconsistent claim in 1938 that the profit was a capital gain. If we assume that the saving in $\operatorname{tax}$ in 1938 amounted to $\$ 19,000$, this much plus $\$ 4,560$ interest thereon (from March 15,1939 , to March 15,1943 ), or a total of $\$ 23,560$, would be added to the excess

$\doteqdot$ Lecturer in Law, New York University; Member of the New York Bar.

1. This section was enacted as section 11 of the Excess Profits Tax Amendments of 1941, effective retroactively to the date of enactment of the Excess Profits Tax Act of 1940 , as amended by the Excess Profits Tax Amendments of 1941, $\S 17$. The section is reproduced as an appendix. (All references in this article to section numbers are to sections of the Internal Revenue Code and corresponding provisions of earlier revenue acts, except where otherwise stated.) For the Treasury regulations interpreting the section, sse U. S. Treas. Reg. 109, $\$ \$ 30.734-1$ et seq. These vere amended by T. D. 5112, 1942-1 Cu2s. BuLI. 153, and after the Revenue Act of 1942 by T. D. 5212, 1943 IsT. REv. BuLn, No. 2 , at 47 .

2. Section 713.

3. The result would be the same if the Commissioner conceded the correctness of the taxpayer's inconsistent position.

4. This interest would be an allowable deduction to $A$ Corporation in 1943. See page 157 et seq. infra. 
profits tax otherwise payable by Corporation $A$ for 1942 . Thus, the original error is corrected and tax justice is presumably achieved, not by collection of additional tax for 1938, but by collection of additional tax for 1942.

That section 734 is "an equitable provision designed not to prevent inconsistency but to discourage such inconsistency by depriving the guilty party of any pecuniary benefit therefrom . . . is evidenced by the fact that an adjustment is not authorized if the party maintaining the inconsistent position is the party who would derive a pecuniary benefit from the adjustment." 5 Thus, if the taxpayer corporation had erroneously capitalized an expenditure in 1938, it could not, by refusing to claim a consistent depreciation in computing its excess profits tax for 1942, reduce the 1942 excess profits tax through adjustment under this section by the income tax overpayment for 1938 . On the other hand, if the corporation in 1942 claims depreciation with respect to the expenditure and the Commissioner disallows such depreciation on the ground that the expenditure was fully deductible in 1938, the section operates because the Commissioner, who is maintaining the inconsistent position, ${ }^{\circ}$ is the party who would be adversely affected ${ }^{\tau}$ by the adjustment.

The problem which section 734 is designed to solve is not a new one. Tax litigants, like litigants in other fields of law, have from time immemorial tried to take advantage of their own errors; and very often they have succeeded. ${ }^{8}$ While it is true that courts, in an effort to prevent unconscionable results, have developed certain corrective doctrines, such as estoppel, ${ }^{9}$ recoupment or set-off,,${ }^{10}$ and election, ${ }^{11}$ these doctrines are ill-defined and limited in their scope, and altogether too uncertain in their application to furnish a satisfactory solution to the problem. Nor do they always achieve the same result as if the error had not been committed. ${ }^{12}$ Moreover, the doctrine of estoppel operates as practically a oneway street to which only the Government has access; at the taxpayer's end

5. Sen. Rep. No. 1631, 77th Cong., 2d Sess. (1942) 211.

6. This point is discussed page 147 et seq. infra.

7. The adverse effect here referred to is measured solely by the amount of the adjustment, not by the over-all effect of assuming the inconsistent position. See page 153 et seq. infra.

8. See, c.g., Helvering v. Salvage, 297 U. S. 106 (1936); see also 10 MERTENs, LAW OF FEDERAL INCOAIE TAXation (1943) $\S \S 60.03,60.10$.

9. See Firemen's Insurance Co., 30 B. T. A. 1004, 1011-13 (1934).

10. See Stone v. White, 301 U. S. 532 (1937) ; Bull v. United States, 295 U. S. 247 (1935) ; Lewis v. Reynolds, 284 U. S. 281 (1932) ; cf. McEachern v. Rose, 302 U. S. 56 (1937).

11. See Raleigh v. United States, 5 F. Supp. 622 (Ct. Cl. 1934); Estate of Thomas J. Moran, 26 B. T. A. 1154 (1932), aff'd, Moran v. Commissioner, 67 F. (2d) 601 (C. C. A. 1st, 1933) ; cf. Estate of William Steele, 34 B. T. A. 173 (1936).

12. See Maguire, Surrey and Traynor, Section 820 of the Revenuc Act of 1938 (1939) 48 YALE L. J. 509, 511-15. 
the entry is barred. ${ }^{13}$ The inadequacies of these judicial doctrines indicate the appropriateness of legislative action.

Section 734 is not the only Congressional attempt ${ }^{14}$ to eliminate profitable inconsistency. However, even though it is applicable only to excess profits tax liability, it is much broader in scope and application than the

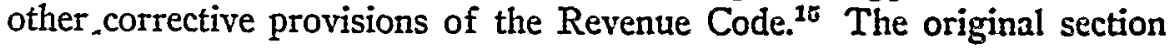

13. 10 MERTENS, op. cit. supra note $8, \$ 60.13$.

14. See section $\$ 20$ and the thorough exposition of this section contained in Maguire, Surrey and Traynor, supra note 12.

15. See sections 3801 and 322(b) (5). While both sections 734 and 3801 are sprung from the same purpose and while some of the language of the two sections is the same or similar, they are not correlated. A particular inconsistency might involve the application of section 734, but not section 3801, or vice versa, or it might involve the application of both sections, or neither section. Section 734 results in increased or decreased excess profits tax liability. Section 3801 results only in the imposition or refund of income tax (including personal holding company surtax and other types of income tax). Section 3801 covers only a limited number of tax inconsistencies, while any error which produces inconsistency is potentially within the scope of section 734. Section 3801 can only affect taxable years as far back as 1932; whereas section 734 may involve computatiuns fir taxable years back to 1913 . The applicability of section 3801 to corporate taxpayers, which are the only ones subject to excess profits tax is, for all practical purposes, limited to cases of inclusion or exclusion of income or deductions in the wrong year coupled with an attempt to take income tax advantage of the error. The other situstions covered by section 3801, i.e., those where the wrong taxpayer has reported income or claimed a deduction and a party seeks to take advantage of the error, are not likely to arise with respect to corporate taxpayers.

Section 322(b) (5) creates a special Statute of Limitations in the case of claims for income tax refunds or credits based on bad debts and worthless securities. Before its enactment the taxpayer had no income tax remedy if he erroneously deducted a bad debt or worthless security loss in an open year and discovered that deduction should have been claimed in a year outlawed by the ordinary Statute of Limitations. The Commissioner upon the adoption of section 3801 had acquired protection against the allowance of such a deduction in the wrong year, but it was believed advisable to exclude the taxpayer from its operation in such a case for the reason that if it were not, the Statute of Limitations so far as bad debts and worthless security losses are concerned would have been emasculated. "The taxpayer who neglected to take a deduction properly allowable for 1935, as to which year the period of limitations on refund claims had expired, could talie that deduction in his return for 1940 , or 1941, etc., or claim a refund for those years, force the Commissioner to take a position inconsistent with the omission of the deduction in 1935, and then, after the Commissioner had won the case, claim an adjustment for 1935." Maguire, Surrey and Traynor, supra note 12, at 758.

The solution offered by $322(b)(5)$ is feasible only where it is limited to a few particular kinds of deduction because extension of the principle to many items of income or deductions would virtually nullify the ordinary statute. The relief accorded by a mere extension of the Statute of Limitations is not, moreover, complete. It does not help the taxpayer if the true loss year is closed for some other reason than the Statute of Limitations, such as res judicata or a closing agreement. In this respect, at least, section 734 supplies a greater safeguard, and is also more helpful to the taspayer in that under it the limitation [contained in section 3771 (d)] on interest on the refund is not applicable. 
and its interpretation by the Treasury, were severely criticized by tax practitioners ${ }^{16}$ who pointed out a number of serious defects, ${ }^{17}$ nearly all of which have been subsequently remedied. Some of the imperfections were removed by way of amended Treasury regulations, ${ }^{18}$ which in 1942 received the approval of the Congressional committees. Others were eliminated by amendments contained in the 1942 Revenue Act. ${ }^{10}$ Since all of the amendments were made retroactive to taxable years beginning after December $31,1939,{ }^{20}$ the amended statute and the amended regulations apply to all excess profits tax years.

\section{Application of the Section}

To whom applicable. Since section 734 operates to increase or decrease only excess profits tax liability, the only taxpayers who will be directly affected by it are corporations subject to that tax. The adjustment provided by the section is made in determining the tax of a "taxpayer under this [excess profits tax] subchapter." ${ }^{21}$ This adjustment, however, may require recomputation of the tax, not only of the taxpayer ${ }^{22}$ itself, but of another taxpayer, if that other taxpayer is a "predecessor" of the taxpayer. Prior to the 1942 Act the statute contained no definition of the term "predecessor" and, as a result, hair-raising situations could be imagined in which the unwary taxpayer might by maintaining an inconsistent position become burdened with tax liabilities of completely unrelated taxpayers. $^{23}$ In the 1942 Act Congress came to the rescue by adding a definition of the term "predecessor." 24 "Predecessor of the taxpayer" includes only: a person which is a "component corporation" of the taxpayer

16. See Anterican Bar Assoctation, Report of Section on Taxation (1942) 7; American Bar Assoctation, Supplenental Report of the Comartitee on ExcessProfits Taxes, Section of Taxation (1941) 5-12; N. Y. State Bar Association Report of Commttre on Taxatron (1942) 211; Blodgett, Pitfalls of Section 734 of the Excess Profits Tax Law (1941) 19 TAxes 643.

17. These are listed in SEN. REP. No. 1631, 77th Cong., 2d Sess. (1942) 211, 212.

18. The original regulations were amended by T. D. 5112, 1942-1 CUr. Buts. 153, amending U. S. Treas. Reg. 109, $\$ \$ 30.734-1,30.734-2$.

19. Revenue Act of $1942, \S 227$ (a).

20. Revenue Act of 1942, §227(b).

21. Section 734(b) (1) (A) (italics supplied). The word "subchapter" refers, of course, to the excess profits tax subchapter of the Code. INT. REv. CoDE (1939) c. 2 (E).

22. Section 734(a) (1) defines taxpayer as "any person subject to a tax under the applicable revenue Act." Presumably, if for any particular year the taxpayer was an exempt corporation and the adjustment did not affect its exempt status, the required adjustment would not take that year into account.

23. See authorities cited supra note 16; see also Hearings before the Ways and Means Contmittee on Revenue Revision of 1942, 77th Cong., 2d Sess. (1942) 173 ct seq., 973 et seq.

24. Section 734(a) (4). 
within the meaning of section 740 ; a person which on April $1,1941,{ }^{25}$ or at any time thereafter, controlled, as defined in Section $112(h),{ }^{20}$ the taxpayer; and a predecessor of a predecessor. ${ }^{2 \pi}$ This definition removes much of the criticism which was directed at section 734 in its original form. since the term is now narrowed to a point where it is believed to include "only those cases in which there is sufficient identity of interest between the parties to warrant their treatment as one for the purpose of the section and to require an adjustment where the treatment of an item for excess profits tax purposes by the one is inconsistent with the treatment of the item by the other for income tax purposes." 28

Where a person after the enactment of section 734 owns at least 80 per cent of the taxpayer's voting stock and at least 80 per cent of all other classes of its stock, ${ }^{29}$ there is apt to be little hardship in charging the taxpayer with the prior inconsistent treatment by the controlling person." Nor is it likely that there will be any miscarriage of justice where the predecessor is a component corporation under section 740 . Under that section the "component corporation" would have to be one that transferred sul-stantially all of its properties to the taxpayer in exchange either for all of the stock or for voting stock of the taxpayer ; ${ }^{31}$ or transferred properties to the taxpayer before October 1, 1940, as paid in surplus or a contribution to capital in respect of voting stock owned by the component; $;^{32}$ or has been merged or consolidated into the taxpayer $;^{33}$ or has been liquidated tax free into the taxpayer under section $112(\mathrm{~b})(6) .^{34}$ The term "component corporation" would also include a partnership or a

25. This was the date of enactment of section 734.

26. Section 112(h) defines control as "the ownership of stocls possessing at least 80 per centum of the total combined voting power of all classes of stock entitled to vote and at least 80 per centum of the total number of shares of all other classes of stocl: of the corporation."

27. "For the purpose of section 734 a component corporation of the taspayer within the meaning of section 740 is a predecessor of the taxpayer even though section 740 is not applicable in the determination of the excess profits tax liability of the taxpayer." SEN. REP. No. 1631, 77th Cong., 2d Sess. (1942) 212.

28. Ibid. The report states: "The definition will cover most of the cases in which the excess profits tax liability of the taxpayer is determined by reference to the base period experience of its predecessor or by reference to the basis of property in the hands of its predecessor. The limitation of the definition to the above cases, and the resulting exclusion of other cases, should not be construed to affect the established judicial doetrines commonly known as estoppel, recoupment, set-off, etc., which may be applied by the courts in appropriate cases." Id. at 212-13. See also U. S. Treas. Reg. 109, §30.734-1.

29. Section $112(\mathrm{~h})$.

30. It is conceivable that there might be some injustice as to the owners of a minority interest.

31. Section 740 (b) (1). Such exchange, of course, would be tax-free.

32. This transaction would also be tax-free.

33. Section 740 (b) (3) and (4).

34. Section 740 (b) (2). 
sole proprietorship business which transferred substantially all of its property to the taxpayer and immediately thereafter controlled the taxpayer. ${ }^{35}$ In all of these situations the identity of the taxpayer and the component corporation is close enough to justify treating them as one and holding the taxpayer responsible for the errors of the "component."

\section{Circumstances of Adjusturent}

Five conditions are prerequisite to application of section 734 . The excess profits credit ${ }^{36}$ treatment of an item or transaction in the excess profits tax taxable year must be inconsistent with the income tax ${ }^{37}$ treatment of the item by the taxpayer or its predecessor in a prior year; the income tax treatment in the prior year must have been incorrect; consistent treatment must result in an increased or decreased income tax liability of the taxpayer or predecessor for the prior year; income tax correction must be prevented (except for section 3801) by the operation of "any law or rule of law" (other than compromises under section 3761); the inconsistent position must be maintained by the party-either the taxpayer or the Government-which would be adversely affected (in so far as the income tax liability of prior years is concerned) by correction of the error. The first four of these conditions may be described as passive constituents of inconsistency. The fifth operates as a catalyst to render the section applicable.

Excess profits credit treatment inconsistent with income tax treatment in prior year. ${ }^{38}$ The statute speaks of the inconsistent treatment of an "item." What is an item? ${ }^{30}$ Dictionaries define it as "a separate particular in an enumeration"; ${ }^{40}$ "one of the separate and distinct things which constitute a whole." ${ }^{41}$ The whole in this case is excess profits credit, and accordingly every thing which has an effect upon that credit is an item, whether it be a particular ${ }^{42}$ of gross income, a particular de-

35. Sections 740 (b) (1), 740(a)(1)(D), 740(h). Such a transfer would be tax-free or partially tax-free under section $112(\mathrm{~b})(5),(\mathrm{c})$ and (e).

36. An inconsistent treatment of an item in determining excess profits net income is not the basis for adjustment under section 734. 7A MERTENs, op. cit. sippra note $8, \S 42.143$.

37. The term "income tax" is hereinafter to be given the technical meaning assigned to it by section 734 (a) (2). See page 143 infra.

38. Section 734(b) (1) (A).

.39. The term is not a new one. See Maguire, Surrey and Traynor, supra note 12, at 751-52. Section 42 speaks of "items of gross income." Sections 22 (b) and 116 refer to items to be included in gross income. Section 24 is entitled "Items Not Deductible." There are probably other statutory provisions which employ the term.

40. Webster's Collegtate Dictionary (5th ed. 1939).

41. Webster's Dictionary of Synonyms (1942).

42. The aggregate of all items of a particular nature would not be an "item" within the meaning of section 734. For example, a net capital gain would not be an item; every detailed transaction entering into the computation of the aggregate would constitute an 
duction, the basis of a particular property, or the amount of a particular indebtedness. The prescribed inconsistency, according to Treasury regulations, may relate either to the rule of law applied in determining the taxable status of the item, or merely to the computed amount of the item, and the measurement of the inconsistency is to be made according to actual treatment of the item in the earlier years rather than the treatment urged by either party in those years. ${ }^{43}$

The statute supplies its own definition of the term "income tax" as used in the phrase "income tax treatment." 4 Such income tax includes not only income taxes in the conventional sense, but other taxes measured by income, such as the penalty surtax on corporations improperly accumulating surplus, the personal holding company surtax, and the excess and war profits taxes imposed during the last war period. ${ }^{45}$ It does not include, however, the declared value excess profits tax, ${ }^{46}$ the excess profits tax on Navy contracts, ${ }^{47}$ the unjust enriclment tax, ${ }^{48}$ and certain other taxes measured by income, such as the tax on transfers to avoid income $\operatorname{tax}^{49}$

The income tax liabilities which are subject to recomputation are only those for a taxable year beginning prior to January 1, 1940, ${ }^{50}$ for the obvious reason that the excess profits tax is only applicable to taxable years beginning after December 31, 1939. It may be taken for granted that items which affect the net income of excess profits tax taxable years will be treated the same for both income and excess profits tax purposes

item. As to inventories, it would seem proper for purposes of section 734 to require the entire inventory to be treated as a unit rather than to permit an inconsistent party to limit his inconsistency to less than all of the ultimate comnonents of the inventory. In this connection, see Gooch Milling \& Elevator Co. v. Commissioner, 133 F. (2d) 131 (C. C. A. Sth, 1943), cert. granted, 319 U. S. 737 (1943), where a taxpayer which was charged with additional income tax by reason of overstatement of its opening inventury for its 1936 fiscal year was allowed an offset ur recoupment on account of the corresponding overstatement of the closing inventory of its 1935 fiscal year. Cases of this sort clearly fall within section 734 and also seem to fall within section 3801 (b) (5).

43. U. S. Treas. Reg. $109, \S 30.734-2$.

44. Section $734(2)(2)$.

45. The taxes included in the definition are those imposed by the following: Ist. Rev. Code (1939) cc. 1 (Income Tax), 2 A (Personal Holding Companies); Revenue Acts of 1938, 1936, 1934, Titles I (Income Tax), I A (Personal Holding Companies); Revenue Acts of 1932, 1928, Title I (Income Tax); Revenue Acts of 1926, 1924, 1921, 1918, Title II (Income Tax); Revenue Acts of 1921, 1918, Title III (IVar Profits and Excess Profits Tax) ; Revenue Act of 1917, Titles I (War Income Tax), II (War Excess Profits Tax); Revenue Act of 1916, Title I (Income Tax); Revenue . Iet of 1913, section II (income tax on individuals and corporations).

46. INT. REv. CODE (1939) c. 2B.

47. INT. Rev. CoDE (1939) C. 2C.

48. INT. REv. CODE (1939) c. 2D.

49. INT. Rev. CODE (1939) c. 7.

50. Section 734(a)(3). 
except where the statute specifically requires or permits different treatment. When the statute does require such different treatment, section 734 has no application. Section 711(b), ${ }^{\text {51 }}$ for example, permits the exclusion of casualty losses in computing base period income ${ }^{52}$ for excess profits tax purposes, but this type of inconsistency requires no adjustment.

Prior income tax treatment incorrect. ${ }^{63}$ Section 734 does not come into play unless the income tax treatment in the prior year was erroncous. In short, the present position must be correct; for otherwise there is no inconsistency. In determining whether the treatment in the prior year was erroneous, the governing law is the law applicable to that year. ${ }^{54}$ If a lessor, for example, reported income in 1937 by reason of coming into possession of a building constructed by its lessee, the fact that under the present law no income results from such a transaction is of no significance. But if the prior income tax treatment was based upon an authoritative judicial interpretation which differs from the interpretation now accepted in the determination of the prior year's income tax liability, it is erroneous within the meaning of the section. ${ }^{55}$ Thus, if a taxpayer in 1934 treated a distribution received from another corporation as nontaxable because of court decisions then controlling and in 1943 the taxpayer asserts that such dividends were taxable because of later decisions holding them taxable, the fact that in 1934 the dividend was commonly considered a return of capital does not prevent the prior treatment from being erroneous.

Consistent treatment resulting in an increased or decreased prior year's income tax liability. ${ }^{56}$ If the correction of the error would result in no increase or decrease in income tax liability of the taxpayer or its predccessor for some prior year, the amount of the adjustment would always be nil. The statute, in such a case, has no application because, under its terms, there must be an increase or decrease. Where a taxpayer, for example, is claiming in 1943 that his accumulated profits should be increased on account of erroneous deductions claimed in certain years prior to 1940

51. U. S. Treas. Reg. 109, $\$ 30.734-2$; H. R. REp. No. 146, 77th Cong., 1st Sess. (1942) 20.

52. However, where, pursuant to the election conferred by section 733, the taxpaycr chooses to capitalize advertising expenditures during the base period, an adjustment under section 734 is required. U. S. Treas. Reg. 109, §30.734-2; H. R. REy. No. 146, 77th Cong., 1st Sess. (1942) 20.

53. Section $734(\mathrm{~b})(2)$.

54. U. S. Treas. Reg. 109, $\$ 30.734-2 ;$ H. R. Rep, No. 146, 77th Cong., 1st Sess. (1942) 20.

55. U. S. Treas. Reg. 109, $\$ 30.734-2$; H. R. Rep. No. 146, 77th Cong., 1st Sess. (1942) 20 . Presumably erroneous treatment which is allowed to remain erroncous mercly because of only prospective application of a decision or ruling is still erroncous.

56. Section 734 (b) (1) (B). 
and the taxpayer in those years sustained large losses, so that the disallowance of the deductions would still leave the taxpayer with no tax liability, one of the requirements is lacking and the section does not operate. The inapplicability of the section would not, of course, preclude the taxpayer from taking the inconsistent position. ${ }^{57}$

Correction prevented. Since the whole purpose of the section is to prevent unconscionable use of a barrier to correction, the section will never be applicable where correction in some other way is possible. Thus, if the period of limitations with respect to the prior year is still open so that the aggrieved party may by proper action obtain redress, the section will not apply. The statute ${ }^{58}$ provides that correction ${ }^{53}$ must be prevented (except for the provisions of section 3801) "by the operation ${ }^{\mathrm{c} \theta}$ of any law or rule of law, other than section 3761, relating to compromises." The most common of such laws or rules of law would be, of course, the Statute of Limitations. The provision would also include the doctrine of res judicata, ${ }^{61}$ the rule against splitting causes of action, ${ }^{62}$ closing agreements under section $3760,{ }^{63}$ and sections $272(f)$ and $322(\mathrm{~b})$ which prohibit all deficiencies, credits, and refunds after the filing of a petition with the Tax Court except those which conform to the requirements of the sections. $^{64}$ Sections 3770,3774 , and 3775 of the Internal Revenue Code relating to payments, refunds, or credits after the period of limitations has expired might also prevent correction of the error.

By specific provision, the fact that correction is permitted under section 3801 does not bar application of section 734. Accordingly, inconsistent treatment may result in the application of both sections. ${ }^{\text {O5 }}$ In such a case, correction under section 3801 will, however, affect the amount of tax previously determined for the prior year, ${ }^{, 6}$ and the financial penalty on the inconsistent party will not be increased because of the concurrent operation of the two sections.

57. Compare Virginian Hotel Corp. v. Helvering, 319 U. S. 523 (1943).

58. Section 734(b) (1) (C).

59. "On the date of such determination of the tax under this subchapter ...."

60. ". . . whether before, on, or after the date of enactment of section 734 ...."

U. S. Treas. Reg. 109, §30.734-2.

61. Section 3801 speaks of correction being prevented by the operation of "any provision of the internal-revenue laws." It might be claimed that this phrase includes only statutory law and not judicial doctrines like res judicata. Presumably for this reason the language of section 734 was made broad enough to include judicial doctrines. See Maguire, Surrey and Traynor, sipra note 12, at 729, 730, 732.

62. Id. at 728 .

63. See id. at 725, n. 67 for discussion of the question whether there is an impairment of contract.

64. Where these sections apply, res judicata and the rule against splitting causes of action may also apply. Miaguire, Surrey and Trainor, supra note 12 , at $\mathbf{7 2 6}$.

65. U. S. Treas. Reg. $109, \S 30.734-2$.

66. U. S. Treas. Reg. 109, $\S 30.734-4$. 
Another specific provision prohibits the application of the section to a prior year in which the income tax liability has been compromised under section 3761. The compromise contemplated by section 3761 is a "formal" compromise specifically effectuated under the provisions of the section. ${ }^{07}$ Undoubtedly, the reason for not applying section 734 where the closed year is a "compromise" year is the difficulty of computing the adjustment in such a case. ${ }^{68}$ Such compromises are usually effected on a dollar basis without reference to any particular treatment of an item and computation of the adjustment would be extremely complex, if not impossible. Particularly is this so in the large number of cases where the compromise is based on "doubt as to collectability" rather than on "doubt as to liability."

"Informal" compromises or settlements, which constitute the great bulk of the actual compromises and settlements entered into by the Treasury Department, ${ }^{09}$ are ostensibly not within the scope of the exception. Yet the reasons which presumably prompted Congress to except formal compromises are frequently applicable to informal settlements. The final tax liability in such cases is often as much a matter of give and take as it is in formal compromises, ${ }^{70}$ even though, on paper, a particular treatment is adopted. ${ }^{71}$ The omission of informal compromise is still a potential defect of section 734 and may ultimately require correction. The provision laying upon the person who would profit from the adjustment the burden of proving that an inconsistent position has been taken ${ }^{72}$ has only partially resolved the difficulty. Assume, for example, that the Commissioner is now asserting that a particular security issued years ago by the taxpayer constitutes indebtedness although in a prior year he had conceded the security to be preferred stock. Assume further that the liability for the earlier year had been settled in such a way that it is impossible to say definitely whether the "dividends" on the "stock" were allowed as a deduction or not. The taxpayer will charge that the Commissioner

67. The section, formerly Rev. Stat. 3229 (1875), is discussed in Paul. Serected Studies in Federal Taxation, Second Sfries (1938) 53 et seq. Section 734 does not specifically mention compromises under REv. STAT. $\$ 3469$ (1875) nor compromises made by the Attorney General under the powers inherent in his office. However, the reasons which prompted Congress to except compromises under section 3761 of the Internal Revenue Code are equally applicable to compromises of the other two types and it seems probable therefore that either of the three types of compromises will constitute a bar to the operation of section 734. See Maguire, Surrey and Traynor, supra note 12, at 733-34, n. 91 .

68. See Maguire, Surrey and Traynor, supra note 12.

69. See Paul, op. cit. sutpra note 67, at 71 .

70. See the example given in PAUL, op. cit. supra note 67, at 71 .

71. See Statement by Excess Profits Tax Committee of American Bar Association, Point (6), Hearings before the Ways and Means Committec on Revente Rezision of 1942, 77th Cong., 2d Sess. (1942) 175.

72. See page 150 et seq. infra. 
is maintaining an inconsistent position, but since the adjustment will be in the taxpayer's faror, he must prove the Commissioner's inconsistency. Because of the nature of the settlement he may be unahle to meet the burden. Despite this possible hardship, it is suggested that before any attempt is made to overhaul the section with a view to eliminating the diffculty, time should be allowed to see how the section works out in practice.

Maintenance of inconsistent position. The four conditions previously discussed remain passive until either the taxpayer or the Government, "in determining at any time" the taxpayer's excess profits tax liability, assumes a position inconsistent with its or its predecessor's prior treatment, which would result in an adjustment to his disadvantage. ${ }^{73}$ In other words, one cannot choose to be inconsistent in order to derive gain from the section. Thus, the maintenance of an inconsistent position by the taxpayer will never invoke section 734 where consistent and correct treatment would result in the payment of lower taxes for the prior years; where the inconsistent position is taken by the Commissioner, the section will apply only if consistent treatment would result in a reduction of tax liability for such prior years. Suppose, for example, that the taxpayer exchanged some property in 1930 and reported the exchange as tax free. It now claims, correctly, that the exchange was taxable and that accordingly its earnings and profits, and hence its invested capital credit, should be increased. Assuming that the inclusion of the gain would have increased the taxpayer's 1930 liability, the section applies. ${ }^{\text {" }}$ The Commissioner, on the other hand, could not by voluntarily increasing the taxpayer's invested capital invoke section 734 and collect additional tax with respect to 1930 .

As another illustration, assume that the Commissioner in auditing the 1940 excess profits tax return of the taxpayer disallows a certain amount of depreciation on the ground that the rates used by the taxpayer in that year were too high. The taxpayer has used the same rates in the years 1936 through 1939, and it is reasonable to conclude, assuming that conditions in those years were the same as in 1940, that if the rates were too high in 1940, they were also too high in the base period years. Clearly, this situation does not authorize the application of section 73,75 since

73. This "disadvantage" refers only to the increase or decrease in prior years' taxes. Presumably, this disadvantage will be more than matched by the excess profits tax gain resulting from the inconsistent treatment; otherwise, the inconsistent party, if well advised, will withdraw from the inconsistent position. See page 149 at seq. infro.

74. If the taxpayer finds that the increase in 1930 tax will be greater than the saving which flows from the increased credit, he will presumably withdraw from the inconsistent position.

75. In this situation the Commissioner would probably find it to his advantage to assert the applicability of the section only if the taxpayer computed its excess profits credit under the invested capital method. 
even if we assume that the Commissioner is maintaining an inconsistent position, correction of the error, that is the adjustment, would result to his advantage. ${ }^{76}$ Suppose, however, that the taxpayer, ultimately conceding the correctness of the Commissioner's disallowance of 1940 depreciation, claims a higher excess profits credit on the ground that the income shown in its returns for 1936-1939 was understated by reason of excessive depreciation. It is then difficult to conclude that the taxpayer is "maintaining" a position when it is forced upon him by the Commissioner. ${ }^{77}$ Moreover, the statutory scheme contemplates that the excessive depreciation in past years will be corrected, pursuant to regulations which have been upheld by the courts, by adjustment of depreciation in future years. For these reasons, it is extremely doubtful whether depreciation adjustments of the type just discussed are within the purview of section 734 .

On the other hand, if the Commissioner asserts that the taxpayer failed to take sufficient depreciation in prior years, so that upon a sale of the depreciable property the gain is greater than that reported by the taxpayer, it would seem that section 734 should apply. In such a case correction of the erroneous under-depreciation other than by section 734 is precluded. ${ }^{78}$

76. Wherever we speak of "advantage" in this connection we refer only to taxes for the prior years. The over-all advantage may be the other way. Sce notes 73 and 74 supra.

77. A somewhat analogous situation exists where the Commissioner disallows compensation as being unreasonable and the same amount of compensation-for the same quality and degree of service-has been paid in the base period years. Such a situation is not on all fours with depreciation, since the excessive deduction in past years is not corrected by reduced deductions in future years.

78. Virginian Hotel Corp. v. Helvering, 319 U. S. 523 (1943). The question of depreciation in connection with section 734 is a troublesome one. In view of sections 114 (a) and $113(\mathrm{~b})(1)(B)$, which provide that the basis upon which depreciation is allowed shall be adjusted for exhaustion, wear, and tear, "to the extent allowed (but not less than the amount allowable) under this chapter or prior income tax laws," is there any inconsistency if, assuming that prior depreciation has been allowed as claimed, either the Commissioner or the taxpayer alleges that the basis for depreciation at the beginning of the excess profits tax taxable year is incorrect? If the Treasury regulations as amended by T. D. 4422, XIV-1 Cumr. BuzL. 58 (1934), are followed literally, there will only be occasion to adjust the basis if the depreciation allowed in the earlier years was less than the amount allowable. U. S. Treas. Reg. 77, 74, art. 265; U. S. Treas. Reg. 69, 62, art. 165. Where the amount allowed was in excess of the amount allowable, no adjustment to basis is permissible. Only the remaining life may be adjusted. To illustrate: assume that at the beginning of 1934 the taxpayer purchased an item of machinery for $\$ 1,000$. He has claimed and been allowed depreciation in the years 1934 through 1939 of ten per cent per annum, so that by the end of 1939 the machine is sixty per cent depreciated-salvage value is ignored. The Commissioner, in auditing 1940 discovers that the asset should have been depreciated at the rate of five per cent per annum and that its remaining life is fourteen years. Accordingly, he takes the remaining basis, $\$ 400$, and dividing it by fourteen he arrives at an annual depreciation for 1940 and subsequent years of $\$ 25.87$. As explained in the text, this action by the Commissioner would not be an 
Since the statute authorizes an adjustment if "at any time" 70 in determining the excess profits tax of the taxpayer an inconsistent position is adopted, a final determination of such tax is not a condition precedent to an adjustment under the section. The filing of an excess profits tax return by the taxpayer is a determination. The assertion of a deficiency by the Commissioner is a determination, as is also the allowance or disallowance of a refund claim. A decision of a court is, of course, a determination. ${ }^{80}$ But the adjustment required by the section does not become final until the determination itself becomes final. Thus, if a decision which adopts an inconsistent treatment is appealed and is reversed, so that the inconsistent treatment is not adopted, the section ceases to apply.

The regulations as originally issued and the legislative committee reports in 1941 were silent on the question whether the party who maintained an inconsistent position could abandon it; and the ambiguity with respect to this point caused some of the most pointed criticisms of the section. $^{81}$ In the absence of a right to withdraw at any time, the taxpayer could unwittingly fall into serious traps without any unconscionable action on his part. ${ }^{82}$ Prudently, the Treasury regulations were changed, ${ }^{83}$ and they now provide:

"Neither the Commissioner nor the taxpayer is required to adopt an inconsistent position with respect to the treatment of an item or transaction in the determination of the excess profits credit .... Such item or transaction may . . . be treated in a manner consistent with the incorrect treatment accorded in the determination of the income tax liability if neither the Commissioner nor the taxpayer

"inconsistency" calling for the application of section 734. But suppose the taxpayer claims that the proper basis for depreciation at the beginning of 1940 is $\$ 700$ (the original cost of $\$ 1,000$ less correct depreciation of $\$ 50$ per year for the six prior years) and that the depreciation properly allowable for 1940 is $\$ 50$. He is perfectly willing to have section 734 apply to his case because the increase in his current depreciation (above what the Commissioner has allowed) and the increase in his excess profits credit will more than make up for the additional tax with respect to the six prior years. At first blush, it might seem that there is an "inconsistency," but on more careful consideration, it will be seen that there is not because the taxpayer's action in 1940 is not "correct" under the regulations relating to depreciation, whereas the Commissioner's action is correct. (It may be noted that in an example in the regulations involving erroneous depreciation, the amount claimed by the taxpayer was less than the amount allowable. See U. S. Treas. Reg. 109, $\$ 30.734-4$.) Another argument that might be used by the Commissioner in this situation is that correction of the original error is not barred. The over-depreciation in prior years will be corrected by under-depreciation in the current and subsequent years. This is not a completely valid argument, however, since the correction does not talse the form contemplated by section 734 .

79. Section $734(\mathrm{~b})(1)(A)$.

80. U. S. Treas. Reg. $109, \S 30.734-2$.

81. Blodgett, supra note 16 , at 643,646 .

S2. Ibid. See also the Bar Association Reports cited supra note 16.

S3. T. D. 5112, 1942-1 Cuar. Bull. 153. 
objects. Either . . . however, may insist upon the correct treatment of such item or transaction . . . but such action constitutes the maintenance of an inconsistent position and will result in an adjustment under section 734 , if the party insisting upon such treatment is the party who would be adversely affected by such adjustment.

"A taxpayer which has taken an inconsistent position with respect to an item or transaction . . . may, upon notice to the Commissioner in writing, withdraw from such position." 84

The committee report on the 1942 Act $^{85}$ stated that the amended regulations correctly interpreted the law and no specific revision of the statute was deemed necessary. In view of this statement there can be no doubt but that the courts will uphold the right of either party to retire from the inconsistent position at any time.

\section{Burden of Proving Inconsistency}

Since, in the usual tax case, the burden of proof is on the taxpayer, section 734 in its original form was severely criticized, because the Commissioner might, by adopting an inconsistent position, impose on the taxpayer the load of proving the correctness of transactions which occurred many years ago. In many cases the records and other papers relating to the transaction might no longer exist or they might never have been available to the taxpayer. Thus, the taxpayer might fail to overcome the Commissioner's inconsistent position through mere inability of proof. ${ }^{80}$

The 1942 Act mitigates, but does not completely eliminate, this difficulty by adding to the section a provision ${ }^{87}$ that in any court proceeding the burden of proving that an inconsistent position has been taken shall be upon the Commissioner where the net effect of the adjustment is an increase in the prior years' income tax and upon the taxpayer where the net effect of the adjustment would be a decrease. ${ }^{88}$ In other words,

84. U. S. Treas. Reg. 109, § 30.734-2. The Commissioner is apparently not required to give any notice; but it is reasonable to expect that, in practice, the Commissioner's intention to withdraw from his inconsistent position will be communicated to the taxpayer.

85. SEN. Rep. No. 1631, 77th Cong., 2d Sess. (1942) 212.

86. Blodgett, supra note 16 , at 650 .

87. Section 734 (b) (3).

88. Sen. Rep. No. 1631, 77th Cong., 2d Sess. (1942) 214. The report adds: "It is not intended that this provision shall be construed to relieve the taxpayer from liability for the penalties imposed for a false or fraudulent return or for a willful failure to stipply the information required by law or regulations made under authority of law." Ibid. And the regulations state: "Inasmuch as the adjustment under section 734 is a factor in the determination of the excess profits tax liability, the provisions relative to the burden of proof in a Board or court proceeding do not relieve the taxpayer from responsibility for a full disclosure of the facts necessary to the correct determination of the tax liability." U. S. Treas. Reg. 109, §734-2. 
the party who would benefit from the adjustment is the party who must bear the burden of proving the inconsistency. Since the section does not operate, at all, unless the party who takes the inconsistent position is the party who would be adversely affected by the adjustment, the party whose inconsistency results in the operation of the section is not the party who must prove inconsistent treatment. Assume. for example, that the Commissioner in auditing the taxpayer's 1940 excess profits tax return asserts that a deduction theretofore allowed the taxpayer in 1935 was properly deductible in 1936. Assume further that the allowance of the deduction in 1936 would result in a greater overpayment for 1936 than the deficiency for 1935. The adjustment. therefore. is against the Commissioner and the section is applicable; but, for the very reason that the adjustment is in favor of the taxpayer, the latter is faced with the burden of proving the Commissioner's inconsistency. Reverse the situation. Assume the taxpayer claims that a deduction previously allowed for 1936 is properly allowable in 1935 , and that the deficiency for 1936 is greater than the overpayment for 1935 . Here the burden of proving the taxpayer's inconsistent treatment will be upon the Commissioner. But the fact that the burden of proving inconsistency is upon the Commissioner does not relieve the taxpayer from his customary burden of establishing the correctness of his present claim that the deduction was properly allowable in $1935 .^{89}$ In actual practice, all the Commissioner must do in such a case is to show that the deduction was claimed and allowed in 1936.

The amendment, therefore, eases the difficulty but does not eliminate it. Loss of the returns or records for the year of wrong treatment might prevent the taxpayer in the first situation or the Commissioner in the reverse situation from proving the inconsistency, with the result that even though there was in fact discrepancy, the inconsistent party could be inconsistent without having to pay the price of his inconsistency.

\section{Method and Amount of Adjustarent}

In computing the cost ${ }^{30}$ of "inconsistency." it may be taken for granted that since the taxpayer has the privilege of withdrawing at any time from an inconsistent position, he will always withdraw if he finds the position unprofitable. Similarly, if the Commissioner realizes that his inconsistency will result in an over-all saving of tax to the taxpayer, he will hardly persevere in the inconsistent position. Therefore, the pitfalls previously envisioned for the section ${ }^{31}$ seem to have disappeared.

89. In this connection, note the caveats quoted supra note 88 .

90. We are here speaking of the amount of the adjustment. As stated in notes 73 and 74 supra, there will presumably be an over-all gain as a result of taking the inconsistent position; otherwise the position will not be taken, or, if talien, it will be abandoned.

91. Blodgett, supra note 16. 
In deciding whether to maintain or abandon the inconsistent position, the party asserting the position will balance against the immediate saving in excess profits tax (before adjustment) not only the amount of the adjustment but also its effect upon future years.

Method of adjustment. ${ }^{92}$ The adjustment required by section 734 rep" resents the net increase or decrease in prior years' income tax liabilities, including interest. With one exception such an adjustment affects only the excess profits tax of the first excess profits tax year in which the inconsistent position is maintained. ${ }^{93}$ That tax will be increased or decreased by the amount of the adjustment. Since the adjustment is added to the excess profits tax liability, the taxpayer always pays the full price for its past error. But prior to the 1942 Act, if the adjustment was a decrease, it could only be used to the extent of the excess profits tax liability before adjustment of the first year in which the inconsistent position was maintained. Thus, the Commissioner had an advantage; he always collected the full price for the taxpayer's inconsistency, but he might not always be required to pay the full price for his own corrected error. If his inconsistency in 1942, for example, produced an overpayment for the prior years of $\$ 100,000$ and excess profits tax liability for 1942 before adjustment was only $\$ 60,000$, the remaining $\$ 40,000$ was lost to the taxpayer. By virtue of an amendment in the 1942 Act, the section now provicles that if the adjustment is a decrease and such decrease exceeds the excess profits tax of the year in which the position is finally adopted, the excess may be applied to reduce excess profits taxes of succeeding taxable years." In the example just stated, the $\$ 40,000$ would be applied to reduce 1943 excess profits tax liability, and if the liability for 1943 before adjustment should be less than $\$ 40,000$, the remainder could be carried forward to 1944 and ad infinitum. ${ }^{95}$

Although the statute makes no specific provision, both the committee reports ${ }^{96}$ and the regulations ${ }^{97}$ state that if a determination of excess profits tax liability for one taxable year requires an adjustment under section 734 with respect to a particular item, similar treatment of the same item for subsequent excess profits tax taxable years does not authorize a further adjustment under the section. Suppose that in 1942 the taxpayer asserts that an exchange in connection with a particular corporate reorganization in 1936 which was treated as tax-free for that year was

92. Section 734(c).

93. It is, of course, assumed that the inconsistent position is not abandoned.

94. Section 734 (c) (4).

95. If excesses result from adjustments with respect to more than one excess profits tax taxable year, such excesses are carried forward in the order of their occurrence. See the example in U. S. Treas. Reg. 109, $\$ 30.734-3$.

96. SEN. REp. No. 1631, 77th Cong., 2d Sess. (1942) 212.

97. U. S. Treas. Reg. 109, §30.734-2. 
not properly tax-free because the continuity of interest test was not met. ${ }^{93}$ The Commissioner acquiesces in this determination and section 734 becomes applicable, so that the taxpayer's 1042 excess profits tax is increased by the increase in 1936 liability, plus interest thereon. The fact that in its 1943 excess profits tax return the taxpayer takes the same position with respect to this transaction as it did in 1942, does not authorize any adjustment in $1943 .^{\text {90 }}$

Amount of adjustment. In $^{\text {Ton }}$ To ascertain the amount which must be added to or subtracted from excess profits tax liability, three separate steps must be taken: the income tax of the taxpayer or its predecessor (or predecessors) must be determined for the closed years affected by the adjustment; the increase or decrease in such tax that would result solely from consistent, that is, correct treatment must be determined; and interest must be added to the increase or decrease. The income tax previously determined for the prior year will be the tax shown on the return plus or minus any changes in that amount. Deficiencies will be added; refunds, credits, and abatements will be subtracted; and if an adjustment under section 3801 has been made, that, ton, must be taken into account. ${ }^{101}$

In computing the increase or decrease resulting "solely" from consistent treatment, the word "solely" is somewhat bothersume. The regulations ${ }^{102}$ and the committee reports ${ }^{103}$ state that in computing the increase or decrease, no item shall be considered except the item which was erroneously treated and the items upon which the tax previously determined was based. ${ }^{104}$ If there are several adjustments with respect to une excess profits tax taxable year, the separate adjustments are aggregated; but in computing the amount of each adjustment, all the other adjustments are ignored. ${ }^{105}$ Take the case, for example, of a corporate taxpayer which succeeded in 1941 to the business of a partnership. In 1942 it asserts that a $\$ 10,000$ item of income, which was reported as income by the predecessor partnership for 1937, properly belonged in 1938. . Issume that the adjustment of 1937-1938 taxes by reason of shifting the income

98. Suppose the taxpayer asserted that the reorganizatiun had no business purpose? If the Commissioner chose to contest this assertion, he might be in the anomalous position of having to prove that the reorganization did have a business purpose.

99. The credit for foreign taxes allowable against excess profits tax, section 729, is computed without giving effect to any adjustment under section 734. U. S. Treas. Reg. $109, \$ 30.73+3$.

100. Section $734(d)$.

101. U. S. Treas. Reg. $109, \S 30.734-4$. If no return was filed, the amount of tax previously determined will consist of deficiencies less refunds, credits, or abatements and plus or minus any adjustment under section 3801.

102. U. S. Treas. Reg. $109, \$ 30.734-4$.

103. H. R. REP. No. 146, 77th Cong., 1st Sess. (1942) 18.

104. U. S. Treas. Reg. 109, § 30.734-4.

105. U. S. Treas. Reg. 109, $\$ 30.734-3$, interpreting section 734 (c) (2). 
to the latter year will be in favor of the Commissioner. The taxpayer also asserts, in 1942 , that a $\$ 10,000$ deduction claimed by the predecessor partnership in 1937 was properly deductible in 1935. Assume the shift of the deduction to the earlier year will again favor the Commissioner. The effect of the shift of income from 1937 and the effect of the shift of the deduction from that year are determined independently of each other. Thus, if the predecessor ${ }^{106}$ were a taxpayer stbject to graduated rates of tax, the decrease with respect to 1937 liability resulting from the first adjustment would be less than the increase resulting from the second adjustment since each adjustment would fall into different tax brackets. Whether such anomalous result was intended by Congress is open to question; but, while there may be individual cases of distortion, the rule set forth in the regulations seems to be a sensible one. If each adjustment were made dependent upon the others, complications would set in, and the recomputation of tax liability would become exceedingly difficult. And since each party has the right to withdraw from each separate inconsistent position at any time, unless the adjustments are computed independently, it will be impossible, where more than one adjustment is involved with respect to the same prior year, for one party to know exactly where he stands and whether it is better for him to recede from the inconsistent position or to pursue it.

As already pointed out, the only items to enter into the adjustment apart from the items which have been inconsistently treated are the items upon which the tax previously determined was based. If in the prior determination the taxpayer overlooked a deduction or the Commissioner omitted an item from gross income and there is no present inconsistency with respect to these omissions, these forgotten items are ignored in the recomputation. While these omissions may produce some distortion, the distortion is not likely to prove serious.

While each adjustment is considered separately, the effect of the adjustment upon all of the items which entered into the previous determination is taken into account. ${ }^{107}$ Thus, if the taxpayer's charitable contriburtions exceeded the allowable percentage ${ }^{108}$ of the income previously de-

106. Presumably where the predecessor is a partnership the adjustment must carry through to the taxes of the individual partners although the literal language of section 734 (a) (4) does not appear to compel this result.

107. U. S. Treas. Reg. $109, \S 30.734-4$, provides: "If the treatment of any item upon which the tax previously determined was based, or if the application of any provisions of the internal revenue laws with respect to such tax depends upon the amount of income (e.g., charitable contributions, foreign tax credit, earned income credit), readjustment of such items in conformity with the change in the amount of the income which results from the correct treatment of the item or transaction in respect of which the inconsistent position was adopted is necessary as part of the recomputation."

108. Five per cent for corporations; fifteen per cent for individuals. See sections $23(q)$ and $(0)$. 
termined and if the adjustment involves an increase in that income, the deduction allowable for such contributions is correspondingly increased. Similarly, a foreign tax credit or the earned income credit might be increased or decreased. Moreover, if the taxpayer was taxed as a personal holding company in the prior year, or if the adjustment is of such a nature that correction of the prior erroneous treatment has the effect of converting the taxpayer into a personal holding company for that prior year, ${ }^{109}$ the computation will involve personal holding company surtax; and, if the taxpayer or its predecessor for the prior year was subjected to the penalty surtax imposed against corporations improperly accumulating surplus, ${ }^{110}$ the recomputation would also require an adjustment of that surtax.111 Still further, it would seem that if an adjustment for one prior year affects another prior year, as, for example, an adjustment which produces or affects a loss carry-over, the tax for the other prior year must also be recomputed. 112

Does the adjustment require a recomputation of the penalties for delinquency, negligence, or fraud if the taxpayer had been held subject to such penalties in the prior year? The statute, the committee reports, and the regulations are silent on this question; but it seems reasonable to conclude that Congress did not mean such penalties to be disturbed. Section 734(d) provides that "To the increase or decrease ... . [in such tax previously determined for such years] there shall be added interest thereon computed as if the increase or decrease constituted a deficiency or an overpayment ...." (italics supplied). A deficiency which is due in any part to negligence or fraud will automatically carry with it the penalties prescribed in section 293; while the penalty for delinquency would attach to the entire tax under section 291. Similarly, an overpayment where these penalties had been imposed would be increased by the penalties erroneously assessed. It might be argued, therefore, that adjustment under section

109. If it were a personal holding company for the year in which the inconsistent position was taken, the section would have no application since such companies are not subject to excess profits tax. If the correction has the effect of converting the taxpayer into a foreign personal holding company for the prior year, recomputation of the shareholder's taxes for that year would only be required if the persons who controlled the taxpayer in such prior year controlled the taxpayer on or after April 1, 1941, that is, if they were "predecessors." See section 734(4) (a).

110. Now INT. Rev. CODE (1939) \$102.

111. It has been suggested that possibly the adjustment could result in the applieation of section 102 where that section had not previously been applied. See Blodgett, supra note 16 , at $644, n$. 4. However, section 102 can only be applied where a particular purpose is present. This is, of course, a subjective test, at least in part; and hence, liability under section 102, such liability not having previously been determined, is not susceptible of automatic adjustment.

112. H. R. REp. No. 146, 77th Cong., 1st Sess. (1942) 17. In this respect, section 734 apparently differs from section 3801 . See Maguire, Surrey and Traynor, suspro note 12 , at 743 . 
734 requires recomputation of penalties. On the other hand, it may more plausibly be argued that in view of the specific provision for the addition of "interest" to the increase or decrease, the failure to mention othcr additions to the tax means that penalties are not to be increased or decreased. Deficiencies and overpayments automatically carry interest as well as penalties, and it would, therefore, seem likely that if Congress meant the adjustment to include recomputation of penalties, it would either have omitted specific mention of interest or specifically mentioned other addlitions. This conclusion is buttressed by the fact that in section 3801 Congress does specifically mention additions to the tax other than interest: "The amount so ascertained (together with any amounts wrongfully collected, as additions to the tax or interest, as a result of such error) shall be the amount of the adjustment under this section." 113 The leading commentators on section 3801 appear to conclude that an adjustment under that section carries with it adjustment of penalties. ${ }^{114}$ But in view of the marked difference in language between the two sections, such a conclusion can hardly apply under section $734 .{ }^{115}$

Interest has been included in the adjustment in an effort to balance the scales of justice delicately. As originally enacted, the section simply required the addition to the increase or decrease in the prior year's tax liability of interest "as if the increase or decrease constituted a deficiency" or an overpayment, as the case may be, for such prior taxable year." But the statute was silent as to the date to which such interest should be computed. The Treasury regulations interpreted the statute to mean that interest was to be "computed to the 15th day of the third month following the close of the excess profits tax taxable year with respect to which the determination . . . is made." 116 Doubt as to the accuracy of this interpretation ${ }^{117}$ was removed by the 1942 Act which sanctions it by inserting its very language into the statute itself. ${ }^{118}$ As in the case of the computation of the increase or decrease in tax liability, the interest is computed with respect to each increase or decrease separately. ${ }^{110}$

While there is no longer uncertainty as to the date to which intercst is computed, some doubt remains as to the date from which interest is computed. On this point the statute, the committee reports and the regulations (except by implication) are silent. Interest is computed "as if the

113. Section 3801(d).

114. See Maguire, Surrey and Traynor, supra note 12 , at 747.

115. Still further, in case there is a fraud penalty, is not correction permitted in the ordinary manner so that the section does not apply? See section 276(a). The inclusion of penalties in the adjustment might produce hardship if the taxpayer did not contest the penalty merely because it was too trivial to warrant controversy.

116. U. S. Treas. Reg. 109, § 30.734-4.

117. Ser. REp. No. 1631, 77th Cong., 2d Sess. (1942) 213.

118. Section 734(d).

119. U. S. Treas. Reg. 109, §30.734-4. 
increase or decrease constituted a deficiency or an overpayment." 120 A deficiency carries interest from the date prescribed for the payment of the first instalment of tax. In the case of an increase, it is clear, therefore, that the interest would be computed from the fifteenth day of the third month following the close of the prior year with respect to which the recomputation is made. ${ }^{121}$ In the case of an overpayment, however, interest is calculated from the date of the overpayment. ${ }^{122}$ Accordingly, the Treasury might have asserted that interest added to decreases is to be computed only from the actual date of overpayment. But in an example given in the regulations, ${ }^{123}$ the interest on both decreases and increases is computed from the fifteenth day of the third month following the close of the taxable year. This would seem to accord with the intent of the statute. ${ }^{124}$

One minor criticism of the original section with respect to interest is still valid. Since the interest on the prior year's tax is included in the determination of the excess profits tax deficiency or overpayment there is a compounding of the interest on the prior year's liability. ${ }^{125}$ This objection, however, is de minimus.

Treatment, as an income or deduction item, of interest included in the adjustment. As originally enacted the section was somewhat ambiguous on the question whether interest on the prior year's tax included in the adjustment retained its character for tax purposes. ${ }^{123}$ This difficulty was resolved by an amendment adding a new subsection ${ }^{12 \pi}$ which clearly indicates that the interest does retain its character as such and constitutes either a deduction, in case of an increase, or income, in case of a decrease. Moreover, the same subsection specifically designates the year in which the interest is entered as an income item or a deduction. The year prescribed is the one in which falls the date prescribed for the payment of the excess profits tax. The year is the same regardless of the method of accounting (cash, accrual, etc.) employed by the taxpayer for its excess profits tax year. ${ }^{128}$ Where there are both increases and decreases affecting

120. Section $734(\mathrm{~d})$.

121: Section 292.

122. Section 3771.

123. U. S. Treas. Reg. $109, \S 30.734-4$.

124. This is borne out by the fact that if interest on decreases were required to be computed from the actual date of overpayment, and the overpayment itself included interest, interest on interest would have to be computed to really put the parties in siatis quo. The section does not appear to contemplate the calculation of interest on interest.

125. Blodgett, supra note 16 , at 650 .

126. Ibid. See also SEN. Kep. No. 1631, 77th Cong., 2d Sess. (1942). The original regulations, even after T. D. 5112, 1942-1 CuM. BuL.. 153, did not cover the point.

127. Section 734(e).

128. "The date prescribed for payment of the [excess profits] tax is, in the case of a domestic corporation, the 15th day of the third month following the close of the tarable year and, in the case of a foreign corporation not having an office or place of business 
the same excess profits tax taxable year the interest factor in each increase and decrease is separated out and the net of all such interest factors is either income or a deduction.

Where section $734(\mathrm{c})(4)^{120}$ is involved, that is, where there is a carryover of decrease because the decrease with respect to the prior year exceeds the excess profits tax liability of the year in which the inconsistent position is maintained, the regulations provide that "no portion of the amount subtracted in any taxable year shall be deemed to represent interest until the portion of the net decrease which represents tax has been exhausted." 130

\section{ConCLUSTON}

Now that we have section 734, what should we do about it? The American Bar Association's Excess Profits Tax Committee and the Taxation Committee of the New York State Bar Association, at one time, asked for its repeal. But most, if not all, of the grounds upon which their objections were based ${ }^{131}$ have been removed by subsequent amendments. Nor does the objection that the section unnecessarily revives old questions seem meritorious. While the advantages of a statute of repose are too well established to require discussion, one can hardly cavil at the soundness of the proposition that no one shall be permitted to take advantage of his own wrong. Both objectives are reconcilable. A Statute of Limitations is supposed to be used only as a shield, not as a weapon, and once a defendant himself revives a claim and uses it as a springboard of attack, the reasons for a statute of repose fall away.

Nor is the cure afforded by the section worse than the disease it seeks to remedy. It does not compel correction of honest mistakes. Such mis-

in the United States, the 15th day of the sixth month following the close of the taxable year, except that, in the case of a taxable year ending before December 31, 1940, the date prescribed for payment of the tax of either a domestic or a foreign corporation is March 15, 1941." U. S. Treas. Reg. 109, \$30.734-5, 3 C. C. H. 1943 Fed. Tax Serv. If 48224-A.

129. See page 152 supra.

130. U. S. Treas. Reg. 109, $\$ 30.734-5,3$ C. C. H. 1943 Fed. Tax Serv. $\$ 48224-A$. The regulation contains the following example: "For the calendar year 1942, Corporation X had an excess profits tax liability of $\$ 9,000$ (computed without regard to section 734) and an authorized adjustment under section 734 resulting in a net decrease of $\$ 12,000$ of which $\$ 8,000$ represents tax and $\$ 4,000$ represents interest. In giving effect to the adjustment, $\$ 9,000$ will be subtracted from the tax for 1942 and the balance will be carried over to succeeding taxable years. Since $\$ 8,000$ of the net decrease represents tax, only $\$ 1,000$ of the amount subtracted in 1942 represents interest and hence $\$ 1,000$ will be included as interest in the taxpayer's gross income for 1943. The entire amount of the $\$ 3,000$ to be carried over and subtracted from the tax for a succeeding taxable year represents interest since the portion of the net decrease which represents tax is exhausted in 1942."

131. Most of these are listed in the Hearings before the Ways and Mcans Committee on Revemue Revision of 1942, 77th Cong., 2d Sess. (1942) 174. 
takes are bound to occur, and it is better to let them remain as honest mistakes than to try to correct them years afterwards when memories are dim and witnesses and papers no longer exist. But an honest mistake ceases to remain honest when the errant party seeks correction without giving up the advantage he originally derived. This is not to say that more tax should be paid by reason of the error than if it had not been made. ${ }^{132}$ Section 734 (and likewise section 3801) makes the errant party pay no more than if he had not made the error in the first instance. Except to the extent that the interest added under the section may exceed the rate of return on the use of the money in the meantime, the parties are no worse off.

Admittedly, section 734 is a complicated and difficult section. Its possibilities are limited only by the imagination. In this discussion, a number of possible applications are presented, but they constitute only a small fraction of the number which might arise. There may and probably will be hard cases, but hard cases in tax law are inevitable. Absolute certainty and precise equality are mirages. Section $73+$ is no more nor less perfect than the whole tax law. It deserves a fair trial.

\section{APPENDIX: SECTION 734}

Adjustment in case of position inconsistent with prior income lax liability

(a) Definitions. For the purposes of this section-

(1) Taxpayer. The term "taxpayer" means any person subject to a tax under the applicable revenue Act.

(2) Income tax. The term "income tax" means an income tax imposed by Chapter 1 or Chapter $2 \mathrm{~A}$ of this title; Title I and Title IA of the Revenue Acts of 1938, 1936, and 1934; Title I of the Revenue Acts of 1932 and 1923; Title II of the Revenue Acts of 1926 and 1924; Title II of the Revenue Acts of 1921 and 1918; Title I of the Revenue Act of 1917; Title I of the Revenue Act of 1916; or section II of the Act of October 3, 1913; a war profits or eveess profits tax imposed by Title III of the Revenue Acts of 1921 and 1918; or Title II of the Revenue Act of 1917; or an income, war profits, or excess profits tax: imposed by any of the foregoing provisions, as amended or supplemented.

(3) Prior taxable jear. A taxable year beginning after December 31, 1939, shall not be considered a prior taxable year.

(4) The term "predecessor of the taxpayer" means-

(A) A person which is a component corporation of the taxpayer within the meaning of section 740 ; and

(B) A person which on April 1, 1941, or at any time thereafter, controlled the taxpayer. The term "controlled" as herein used shall have the same meaning as "control" under section 112(h), and

(C) Any person in an unbroken series ending with the taxpayer if subparagraph (A) or (B) would apply to the relstionship between the parties.

132. The doctrine of estoppel might put him in such a position, and this is probably one of the reasons the courts are loath to apply the estoppel theory. 
(b) Circumstances of adjustment.

(1) If-

(A) in determining at any time the tax of a taxpayer under this subchapter an item affecting the determination of the excess profits credit is treated in a manner inconsistent with the treatment accorded such item in the determination of the income-tax liability of such taxpayer or a predecessor for a prior taxable year or years, and

(B) the treatment of such item in the prior taxable year or years consistently with the determination under this subchapter would effect an increasc or decrease in the amount of the income taxes previously determined for such taxable year or years, and

(C) on the date of such determination of the tax under this subchapter correction of the effect of the inconsistent treatment in any one or more of the prior taxable years is prevented (except for the provisions of section 3801) by the operation of any law or rule of law (ather than section 3761, relating to compromises),

then the correction shall be made by an adjustment under this section. If in a subsequent determination of the tax under this subchapter for such taxable year such inconsistent treatment is not adopted, the correction shall not be made in connection with such subsequent determination.

(2) Such adjustment shall be made only if there is adopted in the determination a position maintained by the Commissioner (in case the net effect of the adjustment would be a decrease in the income taxes previously determined for such year or years) or by the taxpayer with respect to whom the determination is made (in case the net effect of the adjustment would be an increase in the income taxes previously determined for such year or years) which position is inconsistent with the treatment accorded such item in the prior taxable year or years which was not correct under the law applicable to such year.

(3) Burden of proof. In any proceeding before the Board or any court the burden of proof in establishing that an inconsistent position has been taken (A) shall be upon the Commissioner, in case the net effect of the adjustment would be an increase in the income taxes previously determined for the prior taxable year or years, or (B) shall be upon the taxpayer, in case the net effect of the adjustment would be a decrease in the income taxes previously determined for the prior taxable year or years.

\section{(c) Method and effect of adjustment.}

(1) The adjustment authorized by subsection (b), in the amount ascertained as provided in subsection (d), if a net increase shall be added to, and if a net decrease shall be subtracted from, the tax otherwise computed under this subchapter for the taxable year with respect to which such inconsistent position is adopted.

(2) If more than one adjustment under this section is made because more than one inconsistent position is adopted with respect to one taxable year under this subchapter, the separate adjustments, each an amount ascertained as provided in subsection (d), shall be aggregated, and the aggregate net increase or decrease shall be added to or subtracted from the tax otherwise computed under this subchapter for the taxable year with respect to which such inconsistent positions are adopted.

(3) If all the adjustments under this section, made on account of the adoption of an inconsistent position or positions with respect to one taxable year under this subchapter, result in an aggregate net increase, the tax imposed by this subchapter shall in no case be less than the amount of such aggregate net increase. 
(4) If all the adjustments under this section, made an account of the adoption of an inconsistent position or positions with respect to a tasable year under this subchapter (hereinafter in this paragraph called the current taxable year), result in an aggregate net decrease, and the amount of such decrease exceeds the tax imposed by this subchapter (without regard to the provisions of this section) for the current taxable year, such excess shall be subtracted from the tax imposed by this subchapter for each succeeding taxable year, but the amount of the excess to be so subtracted shail be reduced by the reduction in tax for intervening taxable years which has resulted from the subtraction of such excess from the tax imposed for each such year.

(d) Asccrtainment of amount of adjus/ment. In computing the amount of an adjustment under this section there shall first be ascertained the amount of the income taxes previously determined for each of the prior taxable years for which correction is prevented. The amount of each such tax previously determined for each such taxable year shall be (1) the tax shown by the taxpayer, or by the predecessor, upon the return for such prior taxable year. increased by the amounts previously assessed (or collected without assessment) as deficiencies, and decreased by the amounts previously abated, credited, refunded, or otherwise repaid in respect of such tax; or (2) if no amount was shown as the tax by such taxpayer or such predecessor upon the return, or if no return was made by such taxpayer or such predecessor, then the amounts previously assessed (or collected without assessment) as deficiencies, but such amounts previously assessed, or collected without assessment, shall be decreased by the amounts previously abated, credited, refunded, or otherwise repaid in respect of such tax. There shall then be ascertained the increase or decrease in each such tax previously determined for each such year which results solely from the treatment of the item consistently with the treatment accorded such item in the determination of the tax liability under this subchapter. To the increase or decrease so aseertained for each such tax for each such year there shall be added interest thereon computed as if the increase or decrease constituted a deficiency or an overpayment, as the case may be, for such prior taxable year. Such interest shall be computed to the fifteenth day of the third month following the close of the excess profits tax tamable year with respect to which the determination is made. There shall be ascertaincd the difference between the aggregate of such increases, plus the interest attributable to each, and the aggregate of such decreases, plus the interest attributable to each, and the net increase or decrease so ascertained shall be the amount of the adjustment under this section with respect to the inconsistent treatment of such item.

\section{(e) Interest in case of net incrcase or decrease.}

(1) If an adjustment under this section results in a net decrease, or more than one adjustment results in an aggregate net decrease, the portion of such net decrease or aggregate net decrease, as the case may be, subtracted from the tas which represents interest shall be included in gross income of the tasable year in which falls the date prescribed for the payment of the tax under this subchapter.

(2) If an adjustment under this section results in a net increase, or more than one adjustment results in an aggregate net increase, the portion of such net increase or aggregate net increase, as the case may be, which represents interest shall be allowed as a deduction in computing net income for the tasable year in which falls the date prescribed for the payment of the tax under this subchapter. Added Mar. 7, 1941, c. 10, §11, 55 Stat. 27; amended Oct. 21, 1942, 4:30 p. m., E. W. T., c. 619, Title II, \$227 (a), 56 Stat. 921-23. 